\title{
Syntheses and Electrochemistry of Imidochromium(v) Compounds. Crystal Structure of $\left[\mathrm{PPh}_{4}\right]-$ $\left[\mathrm{Cr}\left(\mathrm{NBu}^{\mathrm{t}}\right) \mathrm{Cl}_{4}\left(\mathrm{OH}_{2}\right)\right] \dagger$
}

\author{
Wa-Hung Leung,*,a Man-Ching Wu, Kwok-Yin Wong, ${ }^{b}$ and $\mathrm{Yu}$ Wang ${ }^{c}$ \\ a Department of Chemistry, The Hong Kong University of Science and Technology, Clear Water Bay, \\ Kowloon. Hong Kong \\ ${ }^{b}$ Applied Biology and Chemical Technology Department, Hong Kong Polytechnic, Hunghom, \\ Kowloon. Hong Kong \\ c Department of Chemistry, National Taiwan University, Roosevelt Road, Section 4, Taipei, Taiwan
}

\begin{abstract}
Reactions of $\left[\mathrm{Cr}\left(\mathrm{NBu}^{t}\right) \mathrm{Cl}_{3}(\mathrm{dme})\right]$ (dme = 1.2-dimethoxyethane) or $\left[\mathrm{PPh}_{4}\right]\left[\mathrm{Cr}\left(\mathrm{NBu}^{t}\right) \mathrm{Cl}_{4}\right]$ with $\mathrm{Tl}\left(\mathrm{C}_{5} \mathrm{H}_{5}\right)$ and $\mathrm{NaL}^{\prime}\left\{\mathrm{L}^{\prime}=\left(\eta-\mathrm{C}_{5} \mathrm{H}_{5}\right)\right.$ Co $\left.\left[\mathrm{PO}(\mathrm{OEt})_{2}\right]_{3}\right\}$ gave respective paramagnetic $\left(\mu_{\mathrm{oft}} \mathrm{ca} .1 .7 \mu_{8}\right)$ half-sandwich imidochromium (v) compounds $\left[\mathrm{CrL}\left(\mathrm{NBu}^{2}\right) \mathrm{Cl}_{2}\right]\left(\mathrm{L}=\eta-\mathrm{C}_{5} \mathrm{H}_{5} 1\right.$ or $\left.\mathrm{L}^{\prime} 2\right)$. The structure of $\left[\mathrm{PPh} \mathrm{h}_{4}\right][\mathrm{Cr}-$ $\left.\left(\mathrm{NBu}^{t}\right) \mathrm{Cl}_{4}\left(\mathrm{OH}_{2}\right)\right]$ has been established by $\mathrm{X}$-ray crystallography. The $\left[\mathrm{Cr}\left(\mathrm{NBu}^{t}\right) \mathrm{Cl}_{4}\left(\mathrm{OH}_{2}\right)\right]^{-}$anion has an octahedral geometry with $\mathrm{Cr}-\mathrm{N}$ (imido) $1.619(3) \AA$. Treatment of $\left[\mathrm{Cr}\left(\mathrm{NBu}^{\mathrm{t}}\right)(\mathrm{L}) \mathrm{Cl}\right]\left[\mathrm{H}_{2} \mathrm{~L}=\right.$ $N, N^{\prime}$-bis(salicylidene)ethane-1,2-diamine or its 3,5-Buz derivative] with $\mathrm{AgBF}_{4}$ afforded cationic imidochromium $(v)$ Schiff-base compounds $\left[\mathrm{Cr}\left(\mathrm{NBu}^{t}\right) L^{2}\right] B F_{4}$. Reactions of the imidochromium(V) compounds with $\mathrm{PPh}_{3}$ at reflux or on irradiation with UV light gave $\mathrm{Ph}_{3} \mathrm{P}=\mathrm{NBu}^{*}$ and $\mathrm{Cr}$ '"'. Cyclic voltammetry of the imidochromium( $V$ ) compounds showed in most cases irreversible oxidation and reduction waves, which are attributed to oxidation and reduction of $\mathrm{Cr}^{2}$.
\end{abstract}

High-valent chromium organometallic compounds are of interest because they are believed to be the reactive intermediates in many chromium-catalysed reactions, e.g. oxidation of hydrocarbons ${ }^{1}$ and oligomerisation and polymerisation of alkenes. $^{2}$ However, organochromium compounds in high oxidation states are rather rare apparently due to the high oxidising power of $\mathrm{Cr}^{\mathrm{VI}}$ and $\mathrm{Cr}^{\mathrm{v}} \cdot{ }^{3}$ Using strong $\pi$-donating imide ligands as stabilising groups, Wilkinson and co-workers ${ }^{4}$ and others ${ }^{5}$ successfully isolated a series of stable dialkylchromium(vi) compounds of the type $\left[\mathrm{Cr}\left(\mathrm{NBu}^{\mathrm{l}}\right)_{2} \mathrm{R}_{2}\right]$. More recently, $\left[\mathrm{Cr}\left(\mathrm{NBu}^{\mathrm{l}}\right) \mathrm{Cl}_{3}(\mathrm{dme})\right]$ (dme = 1,2-dimethoxyethane) and $\left[\mathrm{PPh}_{4}\right]\left[\mathrm{Cr}\left(\mathrm{NBu}^{\prime}\right) \mathrm{Cl}_{4}\right]$ were synthesised and found to be useful starting materials for chromium(v)compounds. However, attempts to synthesise chromium(v) alkyls by alkylation of $\left[\mathrm{Cr}\left(\mathrm{NBu}^{t}\right) \mathrm{Cl}_{3}(\mathrm{dme})\right]$ or $\left[\mathrm{Cr}\left(\mathrm{NBu}^{\prime}\right) \mathrm{Cl}_{4}\right]$ were unsuccessful presumably because of concomitant disproportionation of $\mathrm{Cr}^{\mathrm{v}}$ to $\mathrm{Cr}^{\mathrm{VI}}$ and $\mathrm{Cr}^{\mathrm{IV}}{ }^{6}$ To overcome this problem, we have synthesised imidochromium(v) compounds containing tripodal ancillary ligands such as $\eta-\mathrm{C}_{5} \mathrm{H}_{5}$ and $L^{\prime}=\left(\eta-\mathrm{C}_{5} \mathrm{H}_{5}\right) \mathrm{Co}$ $\left[\mathrm{PO}(\mathrm{OEt})_{2}\right]_{3}$ which should prevent the bimolecular reaction. One potential application of organoimido compounds is their nitrogen-atom-transfer reactions such as amination ${ }^{7}$ and aziridination ${ }^{8}$ of alkenes. Despite the wealth of chemistry of metal-mediated oxo-transfer reactions, there are relatively few studies on transfer of the isoelectronic imido group. ${ }^{9}$ In an effort to understand the thermodynamics governing the reactivity of organoimido compounds, we herein report the syntheses and electrochemistry of some half-sandwich and cationic imidochromium(v) complexes.

\section{Experimental}

All manipulations were carried out under nitrogen using

† Supplementary data available: see Instructions for Authors, J. Chem. Soc., Dalton Trans., 1994, Issue 1, pp. xxiii-xxviii.

Non SI unit employed: $\mu_{\mathrm{B}} \approx 9.27402 \times 10^{-24} \mathrm{~J} \mathrm{~T}^{-1}$.

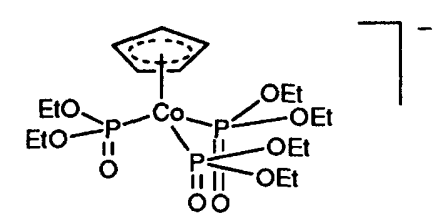

$\mathbf{L}^{\cdot}$

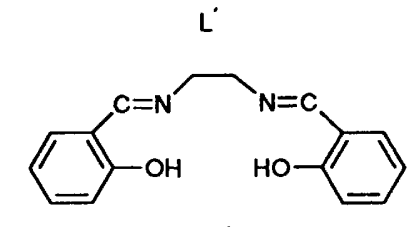

$\mathrm{H}_{2}$ salen

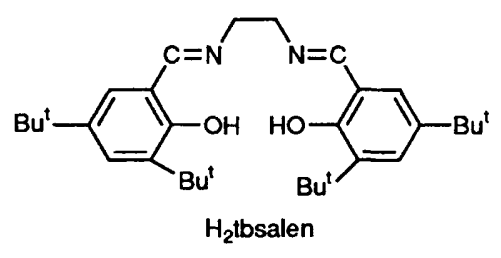

standard Schlenk techniques. Solvents were dried, distilled and degassed prior to use. Infrared spectra (Nujol) were obtained on a Nicolet MAGNA-IR 550 FT-IR spectrophotometer, UV/VIS spectra on a Milton Roy Spectronic 3000 diode-array spectrophotometer and mass spectra on a Kratos MS 80RFAQ spectrometer. Magnetic moments were measured in $\mathrm{CHCl}_{3}$ solutions by the Evans method. ${ }^{10}$ Cyclic voltammetry was performed with a Princeton Applied Research (PAR) model 175 potentiostat. Potentials were with respect to a $\mathrm{Ag}^{+}-\mathrm{Ag}$ reference electrode in acetonitrile, but are reported with respect to the ferrocenium-ferrocene couple as measured in the same solution. Elemental analyses were performed by Medac Ltd., Brunel University, UK.

CAUTION: chromium compounds are potentially car- 
cinogenic and should be handled appropriately, avoiding skin contact and inhalation. The compounds $\mathrm{NaL}^{\prime},{ }^{11}\left[\mathrm{Cr}\left(\mathrm{NBu}^{\mathrm{t}}\right)\right.$ $\left.\mathrm{Cl}_{3}(\mathrm{dme})\right], \quad\left[\mathrm{PPh}_{4}\right]\left[\mathrm{Cr}\left(\mathrm{NBu}^{t}\right) \mathrm{Cl}_{4}\right]$, and $\left[\mathrm{PPh}_{4}\right]\left[\mathrm{Cr}\left(\mathrm{NBu}^{t}\right)-\right.$ $\left.\left(\mathrm{OCMeEtCO}_{2}\right)_{2}\right]$ and $\left[\mathrm{Cr}\left(\mathrm{NBu}^{\mathrm{t}}\right)(\right.$ salen $\left.) \mathrm{Cl}\right]$ were prepared as described elsewhere. ${ }^{6}$ 2,4-Di-tert-butylphenol (Aldrich) and $\mathrm{Tl}\left(\mathrm{C}_{5} \mathrm{H}_{5}\right)$ (Strem) were used as received. The compound $\mathrm{H}_{2}$ tbsalen was synthesised by condensation of 1,2-diaminoethane with 2 equivalents of 3,5-di-tert-butylsalicylaldehyde ${ }^{12}$ in $\mathrm{EtOH}$ and was recrystallised from $\mathrm{EtOH} ; \mathrm{Na}_{2}$ (tbsalen) was prepared by reaction of $\mathrm{H}_{2}$ tbsalen with 2 equivalents of $\mathrm{NaH}$ in tetrahydrofuran.

Preparations. $-\left[\mathrm{Cr}\left(\eta-\mathrm{C}_{5} \mathrm{H}_{5}\right)\left(\mathrm{NBu}^{t}\right) \mathrm{Cl}_{2}\right]$ 1. To a solution of $\left[\mathrm{Cr}\left(\mathrm{NBu}^{\mathrm{t}}\right) \mathrm{Cl}_{3}(\mathrm{dme})\right](0.15 \mathrm{~g}, 0.47 \mathrm{mmol})$ or $\left[\mathrm{PPh}_{4}\right]\left[\mathrm{Cr}\left(\mathrm{NBu}^{\mathrm{t}}\right)-\right.$ $\left.\mathrm{Cl}_{4}\right](0.26 \mathrm{~g}, 0.48 \mathrm{mmol})$ in thf $\left(15 \mathrm{~cm}^{3}\right)$ at $-78^{\circ} \mathrm{C}$ was added 1 equivalent of $\mathrm{Tl}\left(\mathrm{C}_{5} \mathrm{H}_{5}\right)(0.13 \mathrm{~g}, 0.48 \mathrm{mmol})$. The resulting mixture was stirred at room temperature overnight. The volatiles were evaporated in vacuo and the green residue was extracted with toluene. Concentration $\left(5 \mathrm{~cm}^{3}\right)$ and cooling $\left(-40^{\circ} \mathrm{C}\right)$ the extract gave a green microcrystalline solid, which can be further purified by sublimation $\left[150^{\circ} \mathrm{C}, 10^{-3} \mathrm{mmHg}(\mathrm{ca}\right.$. $0.133 \mathrm{~Pa}$ )], yield $50 \%$, m.p. $194^{\circ} \mathrm{C}$ (decomp.). Mass spectrum (electron impact, EI): $m / z: 258\left(M^{+}\right), 223\left(M^{+}-\mathrm{Cl}\right)$ and 152 $\left(M^{+}-\mathrm{Cl}-\mathrm{Bu}^{\mathrm{t}}\right)$. IR: $1031 \mathrm{~cm}^{-1}\left[\mathrm{v}\left(\mathrm{Cr}=\mathrm{NBu}{ }^{t}\right)\right] . \mu_{\text {eff }}=1.7 \mu_{\mathrm{B}}$ (Found: $\mathrm{C}, 40.0 ; \mathrm{H}, 5.6 ; \mathrm{N}, 5.4 . \mathrm{C}_{9} \mathrm{H}_{14} \mathrm{Cl}_{2} \mathrm{CrN}$ requires $\mathrm{C}, 41.7$; $\mathrm{H}, 5.4 ; \mathrm{N}, 5.4 \%$ ). Despite several attempts, we have not been able to obtain good carbon analyses. The corresponding analyses for complexes $\mathbf{3}$ and $\mathbf{4}$ are also lower than the calculated values.

$\left[\mathrm{CrL}^{\prime}\left(\mathrm{NBu}^{\mathrm{t}}\right) \mathrm{Cl}_{2}\right]$ 2. To a solution of $\left[\mathrm{Cr}\left(\mathrm{NBu}^{t}\right) \mathrm{Cl}_{3}(\mathrm{dme})\right]$ $(0.18 \mathrm{~g}, 0.56 \mathrm{~mol})$ or $\left[\mathrm{PPh}_{4}\right]\left[\mathrm{Cr}\left(\mathrm{NBu}^{t}\right) \mathrm{Cl}_{4}\right](0.26 \mathrm{~g}, 0.48 \mathrm{mmol})$ in thf $\left(20 \mathrm{~cm}^{3}\right)$ was added 1 equivalent of $\mathrm{NaL}^{\prime}(0.28 \mathrm{~g}, 0.57$ $\mathrm{mmol})$. The resulting mixture was stirred at room temperature overnight. The volatiles were removed in vacuo and the residue was extracted with toluene. Evaporation of the toluene extract to dryness gave an analytically pure green solid, which can be further recrystallised from thf-hexane. Yield $80 \%$, m.p. $164{ }^{\circ} \mathrm{C}$ (decomp.). IR: $1037 \mathrm{~cm}^{-1}\left[\mathrm{v}\left(\mathrm{Cr}=\mathrm{NBu}^{\mathrm{t}}\right)\right]$ (Found: $\mathrm{C}, 34.3 ; \mathrm{H}, 5.7$; $\mathrm{N}, 1.9 . \mathrm{C}_{21} \mathrm{H}_{44} \mathrm{Cl}_{2} \mathrm{CoCrNO}_{9} \mathrm{P}_{3}$ requires $\mathrm{C}, 34.5 ; \mathrm{H}, 6.0 ; \mathrm{N}$, $1.9 \%$ ). Mass spectrum (EI): $m / z 693\left(M^{+}\right), 658\left(M^{+}-2 \mathrm{Cl}\right)$ and $622\left(M^{+}-\mathrm{Cl}-\mathrm{NBu}^{\mathrm{t}}\right) . \mu_{\mathrm{eff}}=1.6 \mu_{\mathrm{B}}$.

$\left[\mathrm{Cr}\left(\mathrm{NBu}^{t}\right)(\right.$ salen $\left.)\right] \mathrm{BF}_{4}$ 3. To a slurry of $\left[\mathrm{Cr}\left(\mathrm{NBu}^{t}\right)(\right.$ salen $\left.) \mathrm{Cl}\right]$ $(100 \mathrm{mg}, 0.2 \mathrm{mmol})$ in $\mathrm{MeCN}\left(20 \mathrm{~cm}^{3}\right)$ was added $\mathrm{AgBF}_{4}$ (40 mg, $0.2 \mathrm{mmol}$ ) and the mixture stirred at room temperature overnight. The $\mathrm{AgCl}$ was filtered off and the filtrate evaporated to dryness. Recrystallisation of the dark red residue from $\mathrm{CH}_{2} \mathrm{Cl}_{2}-\mathrm{Et}_{2} \mathrm{O}$ gave a brown microcrystalline solid, yield $75 \%$. IR: $1100 \mathrm{~cm}^{-1}\left(\mathrm{BF}_{4}\right)$ (Found: $\mathrm{C}, 48.5 ; \mathrm{H}, 5.1 ; \mathrm{N}, 8.6$. $\mathrm{C}_{20} \mathrm{H}_{23} \mathrm{BCrF}_{4} \mathrm{~N}_{3} \mathrm{O}_{2}$ requires $\mathrm{C}, 50.4 ; \mathrm{H}, 4.8 ; \mathrm{N}, 8.8 \%$ ).

$\left[\mathrm{Cr}\left(\mathrm{NBu}^{t}\right)\right.$ (tbsalen) $] \mathrm{BF}_{4}$ 4. To $\left[\mathrm{Cr}\left(\mathrm{NBu}^{t}\right) \mathrm{Cl}_{3}(\mathrm{dme})\right](0.25 \mathrm{~g}$, $0.78 \mathrm{mmol})$ in thf $\left(20 \mathrm{~cm}^{3}\right)$ was added $\mathrm{Na}_{2}$ (tbsalen) $(0.39 \mathrm{~g}$, $0.79 \mathrm{mmol}$ ) and the reaction mixture stirred at room temperature overnight. After removal of solvent the residue was extracted with hexane. Evaporation of the solvent gave a brown solid, which was dissolved in $\mathrm{CH}_{2} \mathrm{Cl}_{2}$ and 1 equivalent of $\mathrm{AgBF}_{4}$ added. The silver chloride formed was filtered off and the filtrate evaporated to dryness in vacuo. The residue was washed with $\mathrm{Et}_{2} \mathrm{O}$ and recrystallised from thf- $\mathrm{Et}_{2} \mathrm{O}$ at $0{ }^{\circ} \mathrm{C}$ to give dark brown crystals, yield $40 \% . \mu_{\text {eff }}=1.7 \mu_{\mathrm{B}}$. IR: $1057(\mathrm{br}) \mathrm{cm}^{-1}$ $\left[v\left(\mathrm{BF}_{4}\right)\right]$. Mass spectrum (FAB): $m / z$ 613.3, $\left[M-\mathrm{BF}_{4}\right]^{+}$; and 542.2, $\left[M-\mathrm{BF}_{4}-\mathrm{NBu}^{\prime}\right]^{+}$(Found: C, 56.9; H, 7.7; N, 5.9. $\mathrm{C}_{36} \mathrm{H}_{55} \mathrm{BCrF}_{4} \mathrm{~N}_{3} \mathrm{O}_{2} \cdot 2 \mathrm{H}_{2} \mathrm{O}$ requires $\mathrm{C}, 58.7 ; \mathrm{H}, 8.0 ; \mathrm{N}$, $5.7 \%$ ).

Reactions of Imidochromium(v) Compounds with $\mathrm{PPh}_{3}$.(a) Photochemical. Typically, a mixture of complex $4(0.2 \mathrm{~g})$ and an excess of $\mathrm{PPh}_{3}(0.2 \mathrm{~g})$ in thf $\left(10 \mathrm{~cm}^{3}\right)$ in a quartz Schlenk tube was irradiated with a mercury lamp $(\lambda=250 \mathrm{~nm})$ for $2 \mathrm{~h}$. The solvent was removed in vacuo and the residue was extracted with hexane and filtered through a short column of Florasil. The presence of the phosphinimine $\mathrm{Bu}^{\mathrm{t}} \mathrm{N}=\mathrm{PPh}_{3}$ in the hexane extract was confirmed by ${ }^{1} \mathrm{H}$ and ${ }^{31} \mathrm{P}$ NMR spectroscopy $\left(\delta_{\mathrm{p}} 27.4\right)$.

(b) Thermochemical. Typically, a mixture of complex $4(0.2 \mathrm{~g})$ and an excess of $\mathrm{PPh}_{3}(0.2 \mathrm{~g})$ in thf $\left(20 \mathrm{~cm}^{3}\right)$ was heated under reflux overnight and worked up as in $(a)$.

$X$-Ray Crystallography. - Crystals of $\left[\mathrm{PPh}_{4}\right]\left[\mathrm{Cr}\left(\mathrm{NBu}^{\prime}\right) \mathrm{Cl}_{4}{ }^{-}\right.$ $\left.\left(\mathrm{OH}_{2}\right)\right]$ were obtained by slow evaporation of a $\mathrm{CH}_{2} \mathrm{Cl}_{2}-\mathrm{Et}_{2} \mathrm{O}$ solution of $\left[\mathrm{PPh}_{4}\right]\left[\mathrm{Cr}\left(\mathrm{NBu}^{t}\right) \mathrm{Cl}_{4}\right]$ in air overnight. Diffraction measurements were performed on a Enraf-Nonius CAD-4 diffractometer. Details of the data collection and results of the structural analyses are given in Table 1 . All reflections were corrected for Lorentz, polarisation and absorption effects. All data reductions and refinements were performed using the NRCVAX packages. ${ }^{13}$ The structure was solved by the Patterson method and refined by full-matrix least squares; all non-hydrogen atoms were refined anisotropically. Hydrogen atoms on the organic ligands were calculated in idealised positions and were included in the structure-factor calculation. Selected bond lengths and angles are given in Table 2. Final atomic coordinates in Table 3 .

Additional material available from the Cambridge Crystallographic Data Centre comprises $\mathrm{H}$-atom coordinates, thermal parameters and remaining bond lengths and angles.

\section{Results and Discussion}

Syntheses of Half-sandwich Chromium(v) Compounds.-The complexes $\left[\mathrm{Cr}\left(\mathrm{NBu}^{t}\right) \mathrm{Cl}_{3}(\mathrm{dme})\right]$ and $\left[\mathrm{PPh}_{4}\right]\left[\mathrm{Cr}\left(\mathrm{NBu}^{t}\right) \mathrm{Cl}_{4}\right]$ have been proven to be useful starting materials for chromium(v) compounds because they are relatively non-oxidising and airstable. $^{5}$ Their reactions with $\mathrm{NaL}^{\prime}$ and $\mathrm{Tl}\left(\mathrm{C}_{5} \mathrm{H}_{5}\right)$ lead to formation of the respective half-sandwich chromium(v) compounds [CrL( $\left.\left.\mathrm{NBu}^{t}\right) \mathrm{Cl}_{2}\right]\left(\mathrm{L}=\mathrm{C}_{5} \mathrm{H}_{5} 1\right.$ or $\left.\mathrm{L}^{\prime} 2\right)$ in good yields. For the synthesis of $1, \mathrm{Tl}\left(\mathrm{C}_{5} \mathrm{H}_{5}\right)$ was the preferred alkylating agent because the reaction of $\left[\mathrm{Cr}\left(\mathrm{NBu}^{t}\right) \mathrm{Cl}_{3}(\mathrm{dme})\right]$ with $\mathrm{Na}\left(\mathrm{C}_{5} \mathrm{H}_{5}\right)$ resulted in an intractable purple oil, apparently due to reduction of $\mathrm{Cr}^{\mathrm{v}}$ to $\mathrm{Cr}^{\mathrm{IIII}}$. Attempts to synthesise $[\mathrm{Cr}(\eta-$ $\left.\left.\mathrm{C}_{5} \mathrm{Me}_{5}\right)\left(\mathrm{NBu}^{t}\right) \mathrm{Cl}_{2}\right]$ from $\left[\mathrm{Cr}\left(\mathrm{NBu}^{t}\right) \mathrm{Cl}_{3}(\mathrm{dme})\right]$ and $\mathrm{Li}\left(\mathrm{C}_{5} \mathrm{Me}_{5}\right)$ were unsuccessful. Treatment of $\left[\mathrm{Cr}\left(\mathrm{NBu}^{t}\right) \mathrm{Cl}_{3}(\mathrm{dme})\right]$ with $\mathrm{K}\left[\mathrm{HB}(\mathrm{pz})_{3}\right](\mathrm{pz}=$ pyrazolyl $)$ gave a toluene-soluble green solid, presumably $\left[\mathrm{Cr}\left\{\mathrm{HB}(\mathrm{pz})_{3}\right\}\left(\mathrm{NBu}^{\prime}\right) \mathrm{Cl}_{2}\right]$. The IR spectrum shows peaks characteristic of the $\mathrm{HB}(\mathrm{pz})_{3}$ ligand. However, we could not obtain correct analytical results for this compound.

Complexes 1 and 2 are insoluble in hexane but readily dissolve in toluene, thf and $\mathrm{CH}_{2} \mathrm{Cl}_{2}$, in which they are nonconductors. The complex $\left[\mathrm{Cr}\left(\eta-\mathrm{C}_{5} \mathrm{H}_{5}\right)\left(\mathrm{NBu}^{t}\right) \mathrm{Cl}_{2}\right]$ is quite volatile and can be purified by sublimation under vacuum, though with some decomposition. As expected 1 and 2 are paramagnetic with $\mu_{\text {eff }}$ of $c a .1 .7 \mu_{\mathrm{B}}$, consistent with a d ${ }^{1}$ ground-state electronic configuration. Their mass spectra (EI) show peaks corresponding to the molecular ions and the expected fragmentation patterns. The infrared spectra display intense bands at $c a .1030 \mathrm{~cm}^{-1}$, assignable to the $\mathrm{Cr}=\mathrm{NBu}^{\mathrm{t}}$ stretch. Unfortunately we have not been able to obtain $\mathrm{X}$-ray-quality crystals of the half-sandwich chromium(v) compounds.

$X$-Ray Crystallography.-The structure of the imidochromium(v) starting material $\left[\mathrm{PPh}_{4}\right]\left[\mathrm{Cr}\left(\mathrm{NBu}^{t}\right) \mathrm{Cl}_{4}\right]$ was characterised by X-ray crystallography. Long green needles suitable for diffraction study were obtained by slow evaporation of a $\mathrm{CH}_{2} \mathrm{Cl}_{2}-\mathrm{Et}_{2} \mathrm{O}$ solution of $\left[\mathrm{PPh}_{4}\right]\left[\mathrm{Cr}\left(\mathrm{NBu}^{\prime}\right) \mathrm{Cl}_{4}\right]$ in air. Apparently the axial aqua ligand comes from the moisture in the solvent. Fig. 1 shows a perspective view of the $\left[\mathrm{Cr}\left(\mathrm{NBu}^{t}\right)-\right.$ $\left.\mathrm{Cl}_{4}\left(\mathrm{OH}_{2}\right)\right]^{-}$anion; selected bond lengths and angles are given in Table 2. The structure is best described as octahedral with the four $\mathrm{Cl}$ atoms on the equatorial plane. $\mathrm{The} \mathrm{Cr}-\mathrm{N}$ distance of $1.619(3) \AA$ and $\mathrm{Cr}-\mathrm{N}-\mathrm{C}$ angle of $168.9(6)^{\circ}$ are indicative of $\mathrm{Cr}-\mathrm{N}$ multiple-bond character and are normal by comparison with other imidochromium(v) compounds. The $\mathrm{Cr}-\mathrm{Cl}$ bond 


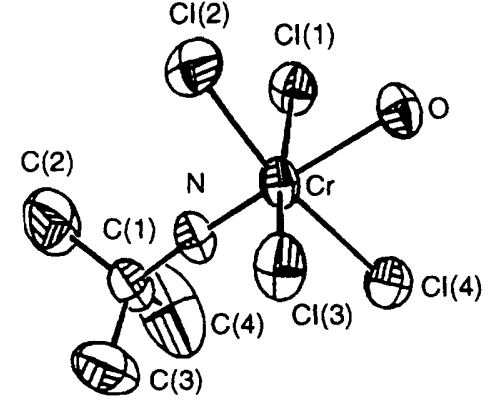

Fig. $1 \mathrm{~A}$ perspective view of the $\left[\mathrm{Cr}\left(\mathrm{NBu}^{t}\right) \mathrm{Cl}_{4}\left(\mathrm{OH}_{2}\right)\right]^{-}$anion. Hydrogen atoms are omitted for clarity

Table 1 Crystal data for $\left[\mathrm{PPh}_{4}\right]\left[\mathrm{Cr}\left(\mathrm{NBu}^{t}\right) \mathrm{Cl}_{4}\left(\mathrm{OH}_{2}\right)\right]$

\begin{tabular}{|c|c|}
\hline $\begin{array}{l}\text { Formula } \\
M\end{array}$ & $\begin{array}{l}\mathrm{C}_{28} \mathrm{H}_{31} \mathrm{Cl}_{4} \mathrm{CrNOP} \\
622.34\end{array}$ \\
\hline Crystal system & Triclinic \\
\hline Space group & $P \bar{I}($ no. 2$)$ \\
\hline$a / \AA$ & $9.320(2)$ \\
\hline$b / \AA$ & $13.072(3)$ \\
\hline$c / \AA \AA$ & $13.246(2)$ \\
\hline$\alpha /^{\circ}$ & $98.75(2)$ \\
\hline$\beta /{ }^{\circ}$ & $107.87(2)$ \\
\hline$\gamma^{\circ}$ & $100.34(2)$ \\
\hline$U / \AA^{3}$ & $1473.5(5)$ \\
\hline$Z$ & 2 \\
\hline$D_{\mathrm{c}} / \mathrm{g} \mathrm{cm}^{3}$ & 1.403 \\
\hline$\lambda(\mathrm{Mo}-\mathrm{K} \alpha) / \AA$ & 0.71069 \\
\hline$F(000)$ & 642 \\
\hline Reflections for unit-cell determination, $2 \theta$ range $/^{\circ}$ & $24,18.91-25.57$ \\
\hline Scan type & $\theta-2 \theta$ \\
\hline $2 \theta$ scan width ${ }^{\circ}$ & $2(0.9+0.35 \tan \theta)$ \\
\hline $2 \theta$ range ${ }^{\circ}$ & $1-45$ \\
\hline$\mu(\mathrm{Mo}-\mathrm{K} \alpha) / \mathrm{cm}^{-1}$ & 8.1 \\
\hline Transmission factors & $0.96-1.0$ \\
\hline Crystal size/mm & $0.4 \times 0.5 \times 0.6$ \\
\hline$T / \mathrm{K}$ & 298 \\
\hline No. of unique reflections & 3837 \\
\hline No. of observed reflections $I \geqslant 2 \sigma(I)$ & 2967 \\
\hline No. of refined parameters & 326 \\
\hline$R, R^{\prime *}$ & $0.039,0.030$ \\
\hline Function minimized & $\Sigma w\left|F_{\mathrm{o}}-F_{\mathrm{c}}\right|^{2}$ \\
\hline Weighting scheme & $1 / \sigma^{2}\left(F_{\mathrm{o}}\right)$ \\
\hline $10^{4} \mathrm{~g}$ (secondary extinction coefficient) & $0.10(9)$ \\
\hline$(\Delta / \sigma)_{\max }$ & 0.11 \\
\hline$(\Delta \rho)_{\max , \min } / \mathrm{e} \AA^{-3}$ & $0.41,-0.41$ \\
\hline $\begin{array}{l}{ }^{*} R=\Sigma\left|F_{\mathrm{o}}-F_{\mathrm{c}}\right| / F_{\mathrm{o}}, R^{\prime}=\left[\Sigma w\left(\mid F_{\mathrm{o}}-F_{\mathrm{c}}\right)^{2} / \Sigma w(\mid F\right. \\
\text { counting statistics. }\end{array}$ & $\left.\left.\left.F_{0}\right|^{2}\right)\right]^{\frac{1}{2}} ; \sigma^{2}\left(F_{0}\right)$ from \\
\hline
\end{tabular}

Table 2 Selected bond lengths $(\AA)$ and angles $\left({ }^{\circ}\right)$ for the $\left[\mathrm{Cr}\left(\mathrm{NBu}^{t}\right)\right.$ $\left.\mathrm{Cl}_{4}\left(\mathrm{OH}_{2}\right)\right]^{-}$anion

\begin{tabular}{llll}
$\mathrm{Cr}-\mathrm{N}$ & $1.619(3)$ & $\mathrm{Cr}-\mathrm{Cl}(1)$ & $2.364(1)$ \\
$\mathrm{Cr}-\mathrm{O}$ & $2.153(3)$ & & \\
$\mathrm{Cl}(1)-\mathrm{Cr}-\mathrm{Cl}(2)$ & $89.01(6)$ & $\mathrm{Cl}(1)-\mathrm{Cr}-\mathrm{N}$ & $92.2(1)$ \\
$\mathrm{Cl}(1)-\mathrm{Cr}-\mathrm{O}$ & $85.01(9)$ & $\mathrm{O}-\mathrm{Cr}-\mathrm{N}$ & $93.1(1)$ \\
\hline
\end{tabular}

length of $2.364(1) \AA$ is slightly longer than those found (2.24 $\AA$ ) for the oxo analogue $\left[\mathrm{CrOCl}_{4}\right]^{-14} \mathrm{The} \mathrm{Cr}-\mathrm{OH}_{2}$ distance of $2.153(3) \AA$ is longer than expected for a $\mathrm{Cr}^{\mathrm{v}}-\mathrm{O}$ bond $\{$ e.g. $\mathrm{Cr}-\mathrm{O}($ cis $)$ distance in $\left[\mathrm{Cr}\left(\mathrm{NBu}^{t}\right) \mathrm{Cl}_{3}(\mathrm{dme})\right]^{6}$ is $\left.2.079(8) \AA\right\}$ apparently due to the trans influence of the imide ligand.

Cationic Imidochromium(v) Compounds.- The study of $\left[\mathrm{Cr}\left(\mathrm{NBu}^{\prime}\right)(\right.$ salen $\left.) \mathrm{Cl}\right]$ was hampered by its poor solubilities in organic solvents. The solubility can, however, be improved by using a more soluble Schiff-base ligand such as $\mathrm{H}_{2}$ tbsalen. Reaction of $\left[\mathrm{Cr}\left(\mathrm{NBu}^{\prime}\right) \mathrm{Cl}_{3}(\mathrm{dme})\right]$ with 1 equivalent of the (a)

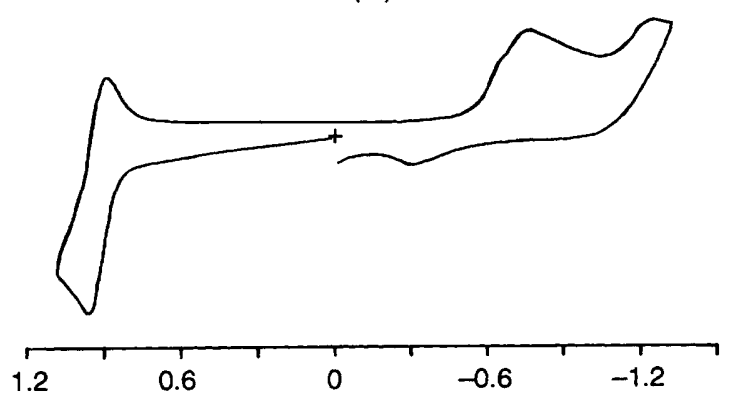

(b)

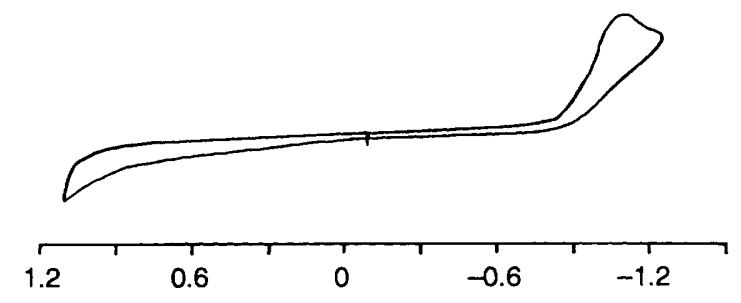

(c)

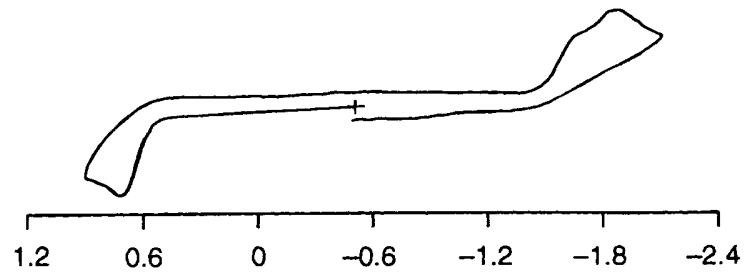

ENvs. ferrocenium-ferrocene

Fig. 2 Cyclic voltammograms of $(a)\left[\mathrm{Cr}\left(\mathrm{NBu}^{\mathrm{t}}\right)(\right.$ tbsalen $\left.)\right] \mathrm{BF}_{4},(b)$ $\left[\mathrm{Cr}\left(\eta-\mathrm{C}_{5} \mathrm{H}_{5}\right)\left(\mathrm{NBu}^{t}\right) \mathrm{Cl}_{2}\right]$ and $(c)\left[\mathrm{Cr}\left(\mathrm{NBu}^{t}\right)\left(\mathrm{OCMeEtCO}_{2}\right)_{2}\right]^{-}$. Working electrode, glassy carbon electrode; scan rate $=100 \mathrm{mV} \mathrm{s}^{-1}$; supporting electrolyte, $0.1 \mathrm{~mol} \mathrm{dm}^{-3}\left[\mathrm{NBu}_{4}\right]\left[\mathrm{BF}_{4}\right]$

sodium salt $\mathrm{Na}_{2}$ (tbsalen) afforded hexane-soluble $\left[\mathrm{Cr}\left(\mathrm{NBu}^{t}\right)\right.$ (tbsalen)Cl] in good yield. Treatment of $[\mathrm{Cr}(\mathrm{NBu})(\mathrm{L}) \mathrm{Cl}][\mathrm{L}=$ salen, or tbsalen) with 1 equivalent of $\mathrm{AgBF}_{4}$ afforded the first cationic imidochromium(v) compounds 3 and 4 , respectively. The measured magnetic moments of $c a .1 .7 \mu_{B}$ for 3 and 4 indicate they are chromium(v) compounds. The IR spectra display broad bands at $c a .1100 \mathrm{~cm}^{-1}$, confirming the presence of the $\mathrm{BF}_{4}{ }^{-}$counter anion. The $v\left(\mathrm{Cr}=\mathrm{NBu}^{t}\right)$ stretch could not be assigned because of overlap with the ligand bands. In contrast to the oxochromium(v) analogues $[\mathrm{Cr}(\text { salen }) \mathrm{O}]^{+}, 3$ and 4 do not react with tertiary phosphines at room temperature. However, under more forcing conditions, imido transfer from $\mathrm{Cr}^{\mathrm{v}}$ to phosphines does occur. For example, reaction between 4 and an excess of $\mathrm{PPh}_{3}$ at reflux yielded the phosphinimine $B u^{t} \mathrm{~N}=\mathrm{PPh}_{3}$, identified by ${ }^{31} \mathrm{P}$ NMR spectroscopy, along with an uncharacterised chromium(III) compound. The imido transfer from $\mathrm{Cr}^{\mathrm{v}}$ to the phosphine is catalysed by UV light. Irradiation of a thf solution of 4 by UV light $(\lambda=250 \mathrm{~nm})$ at room temperature in the presence of $\mathrm{PPh}_{3}$ for $1 \mathrm{~h}$ gave $\mathrm{Bu} \mathrm{U}^{\mathrm{N}}=\mathrm{PPh}_{3}$ in good yield. A similar result was obtained for $\left[\mathrm{Cr}\left(\mathrm{NBu}^{\mathrm{t}}\right) \mathrm{Cl}_{3}\left(\mathrm{PR}_{3}\right)_{2}\right]\left(\mathrm{R}_{3}=\mathrm{Me}_{3}, \mathrm{Me}_{2} \mathrm{Ph}\right.$ or $\left.\mathrm{EtPh}_{2}\right) .{ }^{15}$

Electrochemistry of Imidochromium(v).-The imido group is a powerful $\pi$ donor and hence is capable of stabilising metal

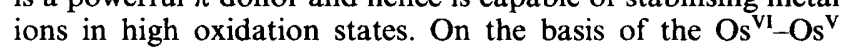
reduction potential for $\left[\mathrm{Os}(\mathrm{X}) \mathrm{Me}_{4}\right]^{n}(n=0$ or $1 ; \mathrm{X}=\mathrm{N}$, $\mathrm{NMe}$, or $\mathrm{O}$ ), Marshman and Shapley ${ }^{16}$ suggested that the $\pi$ donating power of the multiply bonded ligand decreases in the order nitrido $>$ methylimido $>$ oxo. The correlation of redox 
Table 3 Fractional atomic coordinates for $\left[\mathrm{PPh}_{4}\right]\left[\mathrm{Cr}\left(\mathrm{NBu}^{t}\right) \mathrm{Cl}_{4}\left(\mathrm{OH}_{2}\right)\right]$

$\begin{array}{llllllll}\text { Atom } & x & y & z & \text { Atom } & x & y & z \\ \mathrm{Cr} & 0.42081(9) & 0.39997(6) & 0.15773(6) & \mathrm{C}(21) & 0.8990(4) & 0.9633(3) & 0.2433(3) \\ \mathrm{P} & 1.07736(13) & 0.92387(9) & 0.29234(9) & \mathrm{C}(22) & 0.8798(5) & 1.0594(3) & 0.2916(3) \\ \mathrm{Cl}(1) & 0.50074(14) & 0.58736(9) & 0.18626(9) & \mathrm{C}(23) & 0.7378(5) & 1.0852(4) & 0.2534(4) \\ \mathrm{Cl}(2) & 0.63517(16) & 0.40519(10) & 0.30563(10) & \mathrm{C}(24) & 0.6169(5) & 1.0155(4) & 0.1700(4) \\ \mathrm{Cl}(3) & 0.36902(17) & 0.21622(9) & 0.12144(10) & \mathrm{C}(25) & 0.6369(5) & 0.9215(4) & 0.1222(4) \\ \mathrm{Cl}(4) & 0.23621(14) & 0.39184(10) & -0.01113(10) & \mathrm{C}(26) & 0.7772(5) & 0.8949(3) & 0.1567(3) \\ \mathrm{O} & 0.5756(3) & 0.39654(23) & 0.06616(23) & \mathrm{C}(31) & 1.0532(5) & 0.8178(3) & 0.3623(3) \\ \mathrm{N} & 0.2987(4) & 0.4086(3) & 0.2213(3) & \mathrm{C}(32) & 1.1800(5) & 0.8040(3) & 0.4412(3) \\ \mathrm{C}(1) & 0.1859(5) & 0.4240(3) & 0.2693(4) & \mathrm{C}(33) & 1.1620(5) & 0.7207(3) & 0.4931(3) \\ \mathrm{C}(2) & 0.2733(7) & 0.4752(4) & 0.3891(4) & \mathrm{C}(34) & 1.0198(6) & 0.6538(3) & 0.4665(4) \\ \mathrm{C}(3) & 0.0937(8) & 0.4938(5) & 0.2111(6) & \mathrm{C}(35) & 0.8937(5) & 0.6655(3) & 0.3868(4) \\ \mathrm{C}(4) & 0.0839(6) & 0.3175(4) & 0.2574(5) & \mathrm{C}(36) & 0.9104(5) & 0.7485(3) & 0.3340(4) \\ \mathrm{C}(11) & 1.2223(5) & 1.0359(3) & 0.3861(3) & \mathrm{C}(41) & 1.1336(4) & 0.8778(3) & 0.1796(3) \\ \mathrm{C}(12) & 1.3130(5) & 1.1056(3) & 0.3477(3) & \mathrm{C}(42) & 1.1891(5) & 0.7871(3) & 0.1732(3) \\ \mathrm{C}(13) & 1.4148(5) & 1.1964(4) & 0.4185(4) & \mathrm{C}(43) & 1.2346(6) & 0.7522(4) & 0.0867(4) \\ \mathrm{C}(14) & 1.4300(6) & 1.2167(4) & 0.5261(4) & \mathrm{C}(44) & 1.2270(5) & 0.8079(4) & 0.0074(3) \\ \mathrm{C}(15) & 1.3429(6) & 1.1466(4) & 0.5646(4) & \mathrm{C}(45) & 1.1717(5) & 0.8977(4) & 0.0125(3) \\ \mathrm{C}(16) & 1.2379(5) & 1.0582(3) & 0.4945(3) & \mathrm{C}(46) & 0.1233(5) & 0.9335(3) & 0.0973(3)\end{array}$

Table 4 Electrochemical data for imidochromium(v) compounds ${ }^{a}$

Compound
$\left.\left[\mathrm{Cr}^{\mathrm{n}}-\mathrm{C}_{5} \mathrm{H}_{5}\right)\left(\mathrm{NBu}^{t}\right) \mathrm{Cl}_{2}\right]$
$\left[\mathrm{CrL}^{\prime}\left(\mathrm{NBu}^{t}\right) \mathrm{Cl}_{2}\right]$
$\left[\mathrm{PPh}_{4}\right]\left[\mathrm{Cr}\left(\mathrm{NBu}^{\prime}\right) \mathrm{Cl}_{4}\right]$
$\left[\mathrm{PPh}_{4}\right]\left[\mathrm{Cr}\left(\mathrm{NBu}^{\prime}\right)\left(\mathrm{mnt}_{2}\right]^{c}\right.$
$\left[\mathrm{N}\left(\mathrm{PPh}_{3}\right)_{2}\right]\left[\mathrm{Cr}\left(\mathrm{NBu}^{t}\right)\left(\mathrm{OCMeEtCO}_{2}\right)_{2}\right]$
$\left[\mathrm{Cr}\left(\mathrm{NBu}^{\prime}\right)(\mathrm{salen})\right] \mathrm{BF}_{4}$
$\left[\mathrm{Cr}\left(\mathrm{NBu}^{t}\right)(\right.$ tbsalen $\left.)\right] \mathrm{BF}_{4}$

\begin{tabular}{lll}
\cline { 2 - 3 } Solvent & Oxidation & \multicolumn{1}{c}{ Reduction } \\
$\mathrm{CH}_{2} \mathrm{Cl}_{2}$ & & $-1.17^{b}$ \\
$\mathrm{MeCN}$ & 0.65 & $-1.11^{b}-1.89$ \\
$\mathrm{MeCN}$ & $0.82^{b}$ & \\
$\mathrm{MeCN}$ & $0.57^{b}$ & -0.75 \\
$\mathrm{MeCN}$ & $0.70^{b}$ & $-1.63^{b}$ \\
$\mathrm{MeCN}$ & $1.15^{b}$ & $-0.49^{b}$ \\
$\mathrm{MeCN}^{b}$ & 0.90 & $-0.71^{b}$ \\
$\mathrm{CH}_{2} \mathrm{Cl}_{2}$ & 0.96 & $-0.75^{b}$
\end{tabular}

${ }^{a} 0.1 \mathrm{~mol} \mathrm{dm}^{-3}\left[\mathrm{NBu}^{\mathrm{n}}{ }_{4}\right]\left[\mathrm{PF}_{6}\right]$ as supporting electrolyte; scan rate $=100 \mathrm{mV} \mathrm{s}^{-1} .{ }^{b}$ Irreversible. ${ }^{c}$ Ref. 6, mnt $=$ maleonitriledithiolate.

potential with reactivity of oxometal complexes is of interest. Recently, a linear-free-energy relationship between the rate of epoxidation by oxo(porphyrinato)chromium(v) and the $\mathrm{Cr}^{\mathrm{v}}$ $\mathrm{Cr}^{\mathrm{IV}}$ reduction potential has been established, suggesting that electron transfer plays a key role in Cr-mediated oxo-transfer reactions. ${ }^{17}$

In an effort to understand the thermodynamics governing the reactivity of the related imido complexes, we set out to study the electrochemistry of imidochromium(v) complexes using cyclic voltammetry and the data are summarised in Table 4 . The cyclic voltammogram of cationic $\left[\mathrm{Cr}\left(\mathrm{NBu}^{t}\right)(\right.$ tbsalen) $] \mathrm{BF}_{4}$ in $\mathrm{MeCN}$ shown in Fig. 2(a) consists of an irreversible wave at $-0.71 \mathrm{~V}$ and a reversible couple at $0.90 \mathrm{~V}$. The reversible couple $\left(i_{\mathrm{a}} / i_{\mathrm{c}} \approx 1\right.$ and scan-rate independent $)$ is assignable to a ligandcentred oxidation because oxidation of the ligand in $[\mathrm{Cr}$ (tbsalen) $\left(\mathrm{N}_{3}\right)$ ] also occurs at a similar potential. ${ }^{18}$ The irreversible wave at $-0.71 \mathrm{~V}$ is tentatively assigned to the reduction of $\mathrm{Cr}^{\mathrm{v}}$. It might be noted that the reduction of imidochromium(v) occurs at potentials considerably more negative than those for oxochromium(v) compounds, e.g. $E^{\circ}\left(\mathrm{Cr}^{\mathrm{v}}-\mathrm{Cr}^{\mathrm{rV}}\right)$ for $[\mathrm{Cr}(\mathrm{L}) \mathrm{O}]^{+}\left[\mathrm{H}_{2} \mathrm{~L}=2,3\right.$-dimethyl- $N, N^{\prime}$-bis(salicylidene)butane-2,3-diamine $]^{19}$ and $[\mathrm{Cr}(\mathrm{tpp}) \mathrm{O}]^{20}(\mathrm{tpp}=$ 5,10,15,20-tetraphenylporphyrinate dianion) at respectively, 0.63 and $0.71 \mathrm{~V} v s$. saturated calomel electrode, demonstrating the stabilisation of $\mathrm{Cr}^{\mathrm{v}}$ by the imido group. The cyclic voltammogram of 1 [Fig. 2(b)] only shows an irreversible wave at $-1.17 \mathrm{~V}$, attributable to the reduction of $\mathrm{Cr}^{\mathrm{v}}$. As expected anionic imidochromium(v) complexes are reduced at even more negative potentials than are their neutral and cationic analogues, e.g. $-1.63 \mathrm{~V}$ for $\left[\mathrm{Cr}\left(\mathrm{NBu}^{\mathrm{t}}\right)\left(\mathrm{OCMeEtCO}_{2}\right)_{2}\right]^{-}$. The latter complex also shows [Fig. 2(c)] an irreversible wave at $0.70 \mathrm{~V}$, which is tentatively assigned to the oxidation of $\mathrm{Cr}^{\mathrm{v}}$ to $\mathrm{Cr}^{\mathrm{vI}}$.

\section{Acknowledgements}

We thank the Hong Kong University of Science and Technology, Hong Kong Polytechnic, the Hong Kong Research Grants Council, and the National Science Council of the Republic of China for support.

\section{References}

1 J. Muzart, Chem. Rev., 1992, 92, 113; G. Cainelli and G. Garadillo, Chromium Oxidations in Organic Chemistry, Springer, Berlin, 1984.

2 E. A. Benham, P. D. Smith, E. T. Hsieh and M. P. McDaniel, J. Macromol. Sci., Chem., 1988, 25, 259; H. L. Kraus, J. Mol. Catal., 1988, 46, 97 and refs. therein; J. R. Briggs, J. Chem. Sco., Chem. Commun., 1989, 674.

3 S. K. Noh, R. A. Heintz, B. S. Haggerty, A. L. Rheingold and K. H. Theopold, J. Am. Chem. Soc., 1992, 114, 1892.

4 A. C. Sullivan, G. Wilkinson, G. Motevalli and M. B. Hursthouse, J. Chem. Soc., Dalton Trans., 1988, 53; A. A. Danopolous, W. H. Leung, G. Wilkinson, B. Hussain-Bates and M. B. Hursthouse, Polyhedron, 1990, 9, 2625.

5 N. Meijboon and C. J. Schravenin, Organometallics, 1990, 9 , 774

6 W. H. Leung, A. A. Danopolous, G. Wilkinson, B. Hussain-Bates and M. B. Hursthouse, J. Chem. Soc., Dalton Trans., 1991, 2051.

7 P. J. Walsh, A. M. Baranger and R. G. Bergman, J. Am. Chem. Soc., $1992,114,1708$

8 D. Mansuy, J. Chem. Soc., Perkin Trans. 2, 1988, 1517 and refs. therein.

9 E. W. Harlan and R. H. Holm, J. Am. Chem. Soc., 1990, 112, 186. 
10 D. Evans, J. Chem. Soc., 1959, 2003.

11 W. Klaui, Z. Naturforsch., Teil B, 1979, 34, 1403.

12 G. Casiraghi, C. Casnati, G. Puglia, G. Sartori and G. Terenghi, J. Chem. Soc., Perkin Trans. 1, 1980, 1862.

13 NRCVAX, E. J. Gabe, Y. Le Page, J.-P. Charland, F. L. Lee and P. S. White, J. Appl. Crystallogr., 1989, 22, 384.

14 B. Gahan, D. C. Garren, L. H. Hill, F. E. Mabbs, K. K. Hargrave and A. T. McPhail, J. Chem. Soc., Dalton Trans., 1977, 1726.

15 A. A. Danopolous, B. Hussain-Bates, M. B. Hursthouse, W. H. Leung and G. Wilkinson, J. Chem. Soc., Chem. Commun., 1990, 1678.
16 R. W. Marshman and P. A. Shapley, J. Am. Chem. Soc., 1990, 112, 8369.

17 J. M. Garrison, D. Ostovic and T. C. Bruice, J. Am. Chem. Soc., 1989, 111, 4960.

18 W. H. Leung, M. C. Wu and K. Y. Wong, unpublished work 19 K. Srinivasan and J. K. Kochi, Inorg. Chem., 1985, 24, 4671. 20 S. E. Creager and R. W. Murray, Inorg. Chem., 1985, 24, 3824.

Received 17th January 1994; Paper 4/00289J 